AN INVESTIGATION OF RESONANT SIGNALS

Jerald W. Long, 1111

Prepared by Sandia Laboratories, Albuquerque, New Mexico 87185

and Livermare, Callfurnia 94550 fur tlie Uniled States Department of

Energy under Contract DE-AC04-76DP00789.

July 1981

1. Sandia National Laboratories 


\section{DISCLAIMER}

This report was prepared as an account of work sponsored by an agency of the United States Government. Neither the United States Government nor any agency Thereof, nor any of their employees, makes any warranty, express or implied, or assumes any legal liability or responsibility for the accuracy, completeness, or usefulness of any information, apparatus, product, or process disclosed, or represents that its use would not infringe privately owned rights. Reference herein to any specific commercial product, process, or service by trade name, trademark, manufacturer, or otherwise does not necessarily constitute or imply its endorsement, recommendation, or favoring by the United States Government or any agency thereof. The views and opinions of authors expressed herein do not necessarily state or reflect those of the United States Government or any agency thereof. 


\section{DISCLAIMER}

Portions of this document may be illegible in electronic image products. Images are produced from the best available original document. 
Issued by Sandia National Laboratories, operated for the United States Department of Energy by Sandia Corporation.

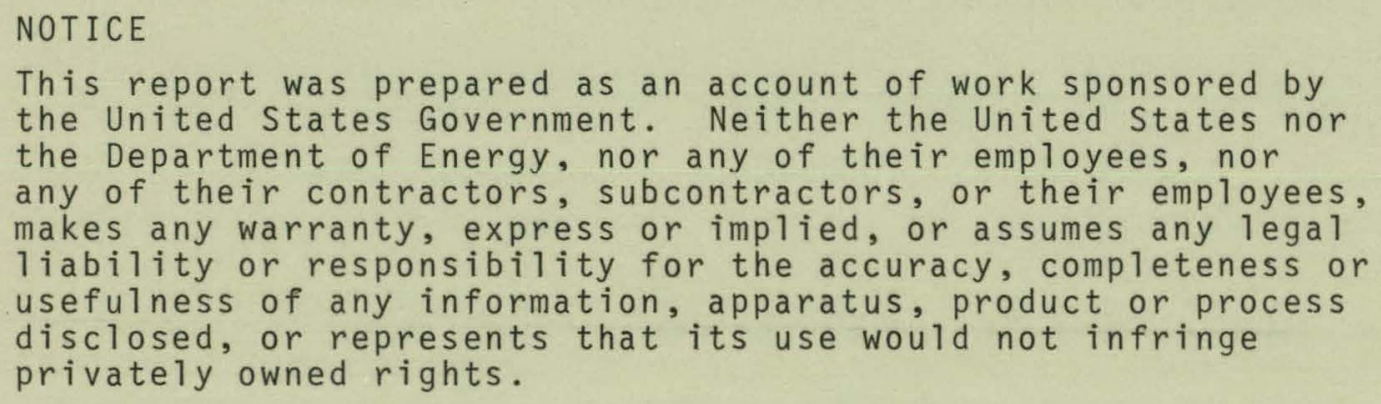

Printed in the United States of America

Available from

National Technical Information Service

U.S. Department of Commerce

5285 Port Royal Road

Springfield, VA 22161

Price: Printed Copy $\$ 4.50$; Microfiche $\$ 3.00$ 


\section{PAGES 1 to 2 WERE INTENTIONALLY LEFT BLANK}


SAND81-1323

Unlimited Release

\title{
AN INVESTIGATION OF RESONANT SIGNALS RECORDED \\ AT WELL J-11, NEVADA TEST SITE
}

by

\author{
Jerald W. Long \\ Ground Motion \& Seismic Division, 1111 \\ Sandia National Laboratories \\ Albuquerque, New Mexico 87185
}

\begin{abstract}
After the Farm event, gages measuring horizontal accelerations. at the bottom of Well $\mathrm{J}-11$ began resonating at about 3 to 5 hertz on each shot. This investigation of possible causes concludes that the material surrounding the well casing has fallen away, allowing the casing to move freely in horizontal directions and causing the undesirable resonance.
\end{abstract}

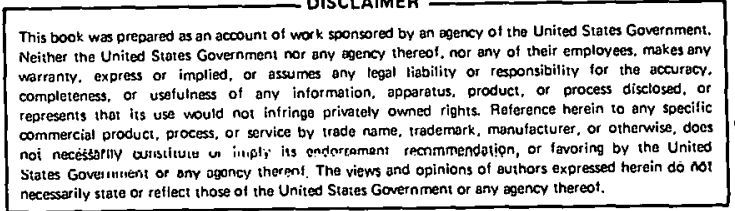




\section{AN INVESTIGATION OF RESONANT SIGNALS RECORDED}

AT WELL J-I1, NEVADA TEST SITE

As a part of the Nevada Nuclear Waste Storage Investigation (NNWSI) at Nevada Test Site, ground motion measurements are being made on selected nuclear weapons tests. Information from these measurements is being used to evaluate the compatibility of a waste repository on or near the test site with weapons tests. Since the repository would be located several hundred meters below the surface, the variation of ground motion waves with depth is of considerable interest. Although much data are avallable for earth motion at the surface, little is available below the surface. In addition, it is expensive to drill holes solely for data collection in each location where a repository site is being considered.

To compensate for this paucity of data below the surface, calculational models are being developed to estimate the earth motion at depth from ground motion acceleration recordings made at the surface. In order to verify the calculational models, canisters containing sets of gages measuring vertical acceleration and two orthogonal horizontal accelerations were installed at the bottoms of existing holes at Nevada Test Site with similar canisters located nearby at the surface.

One canister was installed in water well J-11 at a depth of 356 meters. A second canister was placed in a nearby hole at 61 meters and a third canister at the surface. These three locations were named $W-10$ Bottom, W-10 Prime, and W-10 Top respectively. After recording data for several shots, problems developed with the gages at W-10 Bottom, the cantster was removed, the gages were replaced, and the canister was reinstalled. Figure 1 shows the location for the canister at $W-10$ Bottom. 


\section{DISCLAIMER}

This report was prepared as an account of work sponsored by an agency of the United States Government. Neither the United States Government nor any agency thereof, nor any of their employees, make any warranty, express or implied, or assumes any legal liability or responsibility for the accuracy, completeness, or usefulness of any information, apparatus, product, or process disclosed, or represents that its use would not infringe privately owned rights. Reference herein to any specific commercial product, process, or service by trade name, trademark, manufacturer, or otherwise does not necessarily constitute or imply its endorsement, recommendation, or favoring by the United States Government or any agency thereof. The views and opinions of authors expressed herein do not necessarily state or reflect those of the United States Government or any agency thereof. 


\section{DISCLAIMER}

Portions of this document may be illegible in electronic image products. Images are produced from the best available original document. 
Analysis of the records for W-10 Bottom on the next shot (Farm, December 1978) indicated that there was a problem and that the canister might not be properly emplaced, Accordingly, on January 9, 1979, the cable was pulled taut and sand was dumped in to attempt to stabilize it in a position away from the well casing. On subsequent shots, it was noted that a ringing could be observed in the horizontal data recorded at $W-10$ Bottom that had not been apparent before. This ringing was not evident at $W-10$ Prime, $W-10$ Top, or in the vertical component at $W-10$ Bottom. (Compare Figures 2 and 3.) Since this is the only station where data from three different levels in a neariy vertical line is readily available, it was essential to establish the cause of this resonance and to eliminate it.

Several possible causes for this ringing were suggested, among them the following:

1. The canister used in W-10 Bottom was a different type of canister specially constructed to be slim enough to fit in the hole; the different construction could be the cause of the ringing.

2. The hole is lined with a steel casing; the close proximity of the steel casing could cause the problem, as could the canister touching the casing.

3. The canister is under water which could cause the problem in some unknown fashion.

4. The gages had just been changed; there could be an electrical problem in the gages themselves.

As a first step, the data recorded and processed for gages at all levels at station $W-10$ were studied carefully. The steel casing in 
the hole precluded using a magnetic compass to determine the orientation of the two horizontal gages at W-10 Bottom. Therefore, hodographs (traces of particle motion) of the data recorded at $W-10$ Bottom were made for all shots from Farm through Tafi. Figure 4 is a chronological presentation of the direction of first motion in the horizontal plane as read from the hodographs and illustrates how the orientation of the gages changed twice. Direction of first apparent motion indicates that the radial (nominal direction) gage was oriented at approximately 260 degrees clockwise from north on the farm event. The process of pulling the cable taut and dumping more sand in on the canister apparently changed the orientation of the gages so that the radial gage was pointed to about 135 degrees for shots subsequent to Farm and before Liptauer. A check of field notebooks by responsible personnel indicates that $W-10$ Bottom was adjusted again on February 2, 1980, just before the Liptauer event. Figure 4 confirms that for Liptauer and beyond the orientation of the radial gage had changed to approximately 175 degrees.

Using these approximate orientation angles, the data recorded at station W-10 Bottom were adjusted to get accelerations as they would have been recorded if the radial gage were pointed directly at shot point. The hodographs in Figure 5 are typical of the results after making these adjustments. Data at all other stations have already been adjusted in this same manner, so that direct comparisons can now be made with the radial and tangential accelerations at other stations.

Since it was difficult to identify the ringing with any certainty on a simple acceleration plot, (as in figures 2 and 3 ) a better method for studying the effect was developed. The best results were found by using a "spectograph." The spectograph is implemented with a computer. program designed to separate the different frequencies into bands and to plot each band as in the spectograph shown in figure 6 . Such a 
computer program functions as a "comb filter" [Reference 1, Chapter 12]. Data in Figure 6 is typical of data recorded at NTS at other stations and at W-10 Bottom prior to the Quinella event. Figures 7 and 8 show data recorded on Quinella and Colwick. These spectographs are typical spectographs for station $W-10$ Bottom radial for all shots since Farm. Tangential spectographs are similar. It is evident that the amplitudes seen in the 2 to 4 hertz range are out of proportion with the other frequency bands. If the ringing is present, it can easily be identified in this manner.

Using this diagnostic, an attempt was made to determine the cause of ringing. If the canister construction is the problem, we could reasonably expect to see a similar ringing in the data recorded at Station W-13 Bottom where a similar canister is in use in an uncased hole. Figure 9 shows records from the Tafi event recorded at Station W-13. No ringing is apparent. A similar check on other shots shows nothing unusual at this particular station. It appears then the canister construction is not the problem. The canister at station $W-13$ is under water, thus eliminating the presence of water as the trouble source.

A canister of a different construction was installed at the bottom of the cased dry hole at Station W-11. Spectographs of data obtained from gages at this station were checked and no evidence of ringing could be found. Therefore, the fact that the hole has a metal casing is, in itself, not the problem.

This leaves the possibll1ty lhat the canister is tourhing the metal casing and someliow causing the ringing. To investigate this possibility, a canister was installed directly on the metal casing at the top of the hole and data was recorded for two events. No ringing deveroped, as is illustrated in Figure 10. This does not eliminate this possibility 
entirely, since the frequencies seen in the middle of the casing are not necessarily the same as those at the top. No spectral bands indicate resonance at this new location so the possibility of this contact causing ringing seems quite impossible.

Analysis of the data from the Farm event reveals no ringing of the type seen on Quinella and all subsequent shots, so the gages were functioning when they were installed just before Farm. It is highly unlikely both horizontal component transducers would be changed to cause ringing at identically the same time. However, if such changes did occur, only two incidents could have contributed to the changes. The first was the Farm event, a normal test for NTS, and quite unlikely to inflict gage changes, since the gages are built to survive much stronger ground motion $\left(393 \mathrm{~m} / \mathrm{s}^{2}\right)$. The second incident was the application of tension to the cable and subsequent addition of sand on top of the gage. This is another quite normal operation and very unlikely to cause damage to either gage, much less to both gages at the same time. Recall the vertical gage is still functioning normally.

We have shown that the possibilities suggested previously are all unlikely at best. In searching for other possiblitities, the most likely one suggested was that some change had taken place in the metal casing itself. Specifically, materlal may have fallen away from the outsides of the casing, leaving a vold so that the casing is free to oscillate In horizontal directions but not the vertical. This could cause the ringing we are now seeing since it is not being observed in the vertical accelerations.

The frequency of the ringing is generally consistent from one shot to the next regardless of the direction from which the signal arrives or the size of the event. Generally, the radial gage is ringing at 3 hertz and to a lesser degree at 5 hertz. The tangential gage is 
ringing slightly less, but with the more pronounced ringing at 5 hertz and the lesser ringing at 3 hertz. If the ringing is caused by horizontal resonance of the casing with less than normal damping by the surrounding material, it would tend to ring in a limited range of frequencies. As can be seen in Figure 11 , this appears to be the case with W-10 Bottom.

In order to see what the data recorded at $W-10$ Prime might look like if it were dominated by frequencies simflar to those seen at $W-10$ Bottom, a new filtering program was written to band pass the data using the cutoff features available in a Butterworth filter. The filter chosen was found in a subroutine created by Sam Stearns. [Reference 1, Page $271]$

In addition to the filtering, in order to better simulate the signal seen at W-10 Bottom, a scaling factor, MF, was computed for all W-lo gages using the relative amplitudes of signals at other gages with that at W-10 Bottom radial in the 1.5 to 4.5 hertz frequency range during the main signal passage. This factor was computed using the following formula:

$$
M F=\sqrt{\frac{\sum_{m=1.5}^{4.5} F_{m}^{2}}{\sum_{m=1.5}^{4.5} G_{m}^{2}}}
$$

where $m$ corresponds to a frequency range from 1.5 to 4.5 hertz using a .l hertz slep, $F$ is the discrete Fourier component of the resonating signal at $W-10$ Bottom radial, and $G$ is the discrete rourier transform of the (normal) signal for the gage to be adjusted. MF is then applied to the normal signal to increase its power to that seen in the signal at Station W-10 Bottom radial. Applying this multiplication factor to 
the data from $W-10$ Prime radial and tangential, the resulting spectographs (see Figures 12 and 13 ) show the effect of passing the normal signal from W-10 Prime through a resonant linear system similar to that assumed for W-10 Bottom. Note that here there is a change in scale, but the resulting spectographs for W-10 Prime now look very similar to the spectographs for W-10 Bottom, especially the spectograph for W-10 Bottom tangential. (For a schematic diagram of this process, see Figure 14.)

Thus it appears that 3 to 5 hertz is the frequency range of the signal that is causing the problem. These results are consistent with the transducers being mounted on an oscillating system having two degrees of freedom, just as the well casing would have if it were moving unrestricted at or near the lower end of the well.

In conclusion, the most likely cause of the unwanted resonance at station $W-10$ Bottom is a loss of material surrounding the well casing. This is allowing the casing to sway freely and thus vibrate excessively in the horizontal plane.

our recommendations are:

1. Data recorded for horizontal motion at station W-10 Bottom since farm should not be included in any analys is of ground motion except for signal arrival times and other analysis where the resonant. frequency is not a problem.

2. If more data is to be recorded at this station the canister should be removed, the gages checked and replaced if necessary, and the canister reinstalled with special precautions taken to insure it is not touching the casing. For this purpose, a close-fitting jacket of styrofoam or "bubble" plastic might suffice. This would eliminate touching the well casing as even a remote possibility. 
3. If 2 above is attempted, driling or pumping out some of the sand might allow reinstalling the canister at a deeper depth and change the situation from what it is now.

4. Two and three above are not recommended unless data are desparately needed from this location, since the conclusion of this study is that they would probably not alleviate the problem. If, however, the hole could be drilled out so the canister could be installed below the end of the casing, the problem could be eliminated.

Reference

1. Digital Signal Analysis, Samuel D. Stearns, Hayden Book Company, 1975. 

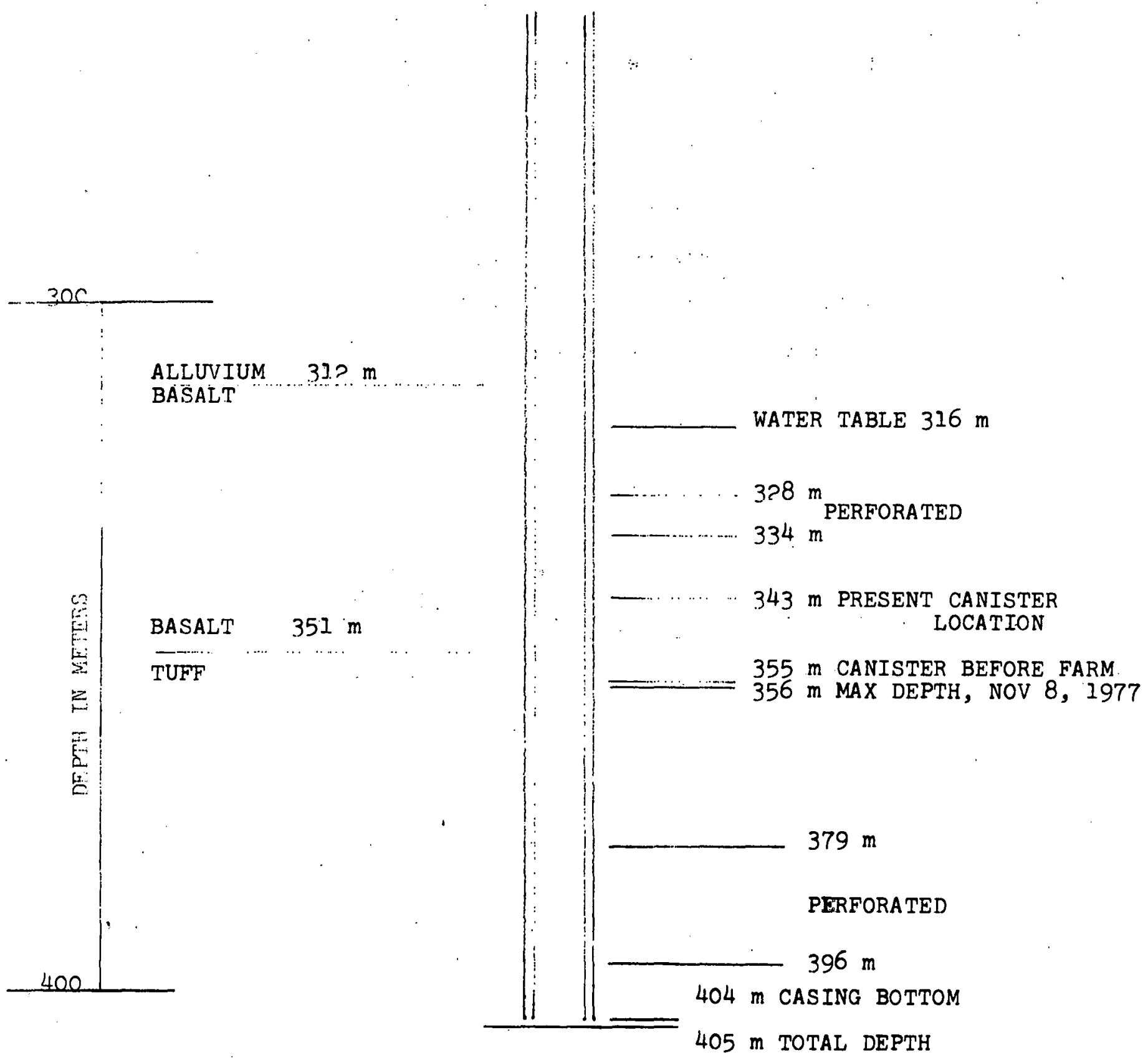

Figure 1 Dlagram of conister location at wlo Bottom 


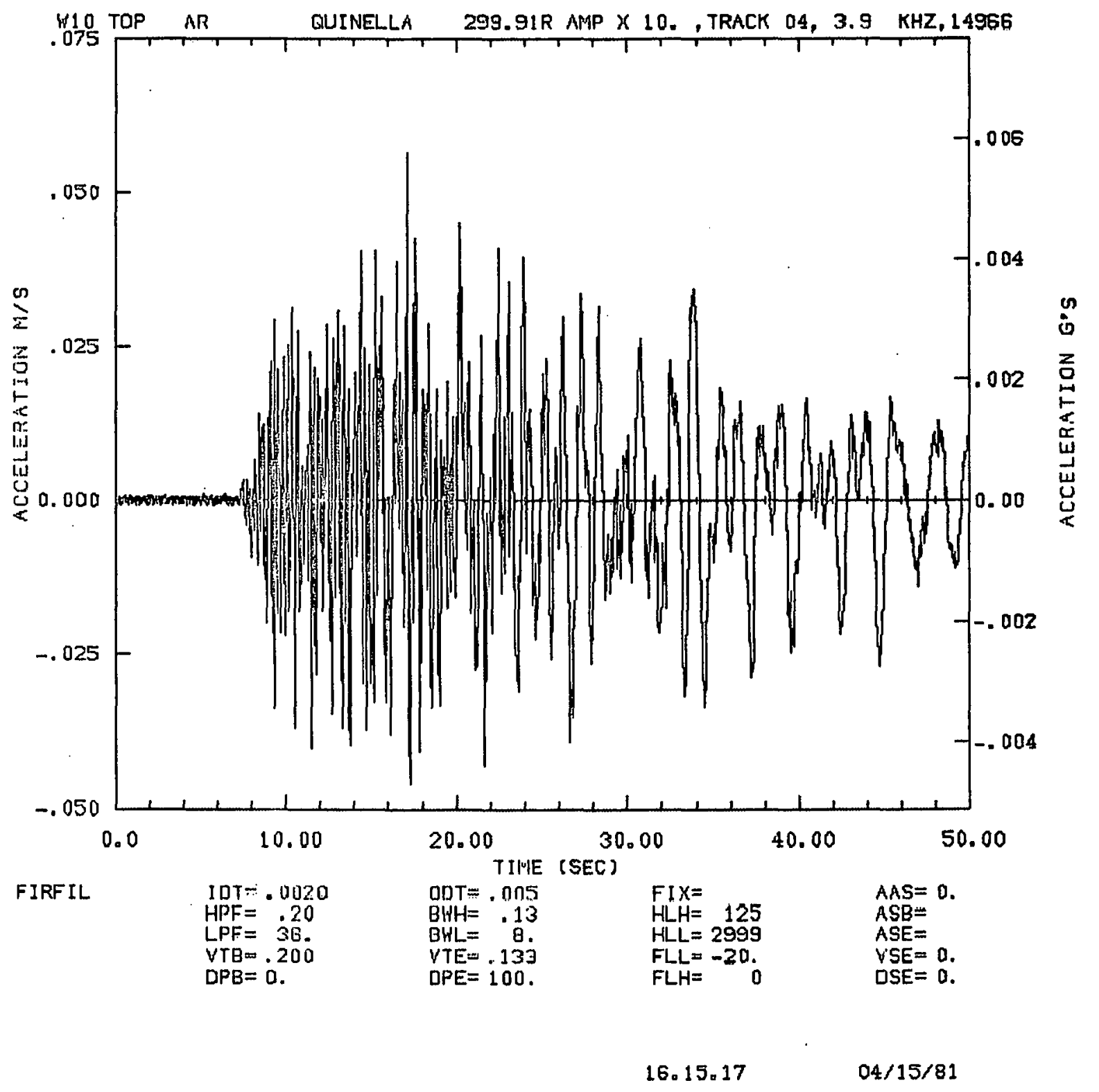

Figure 2. Normal Acceleration Record 


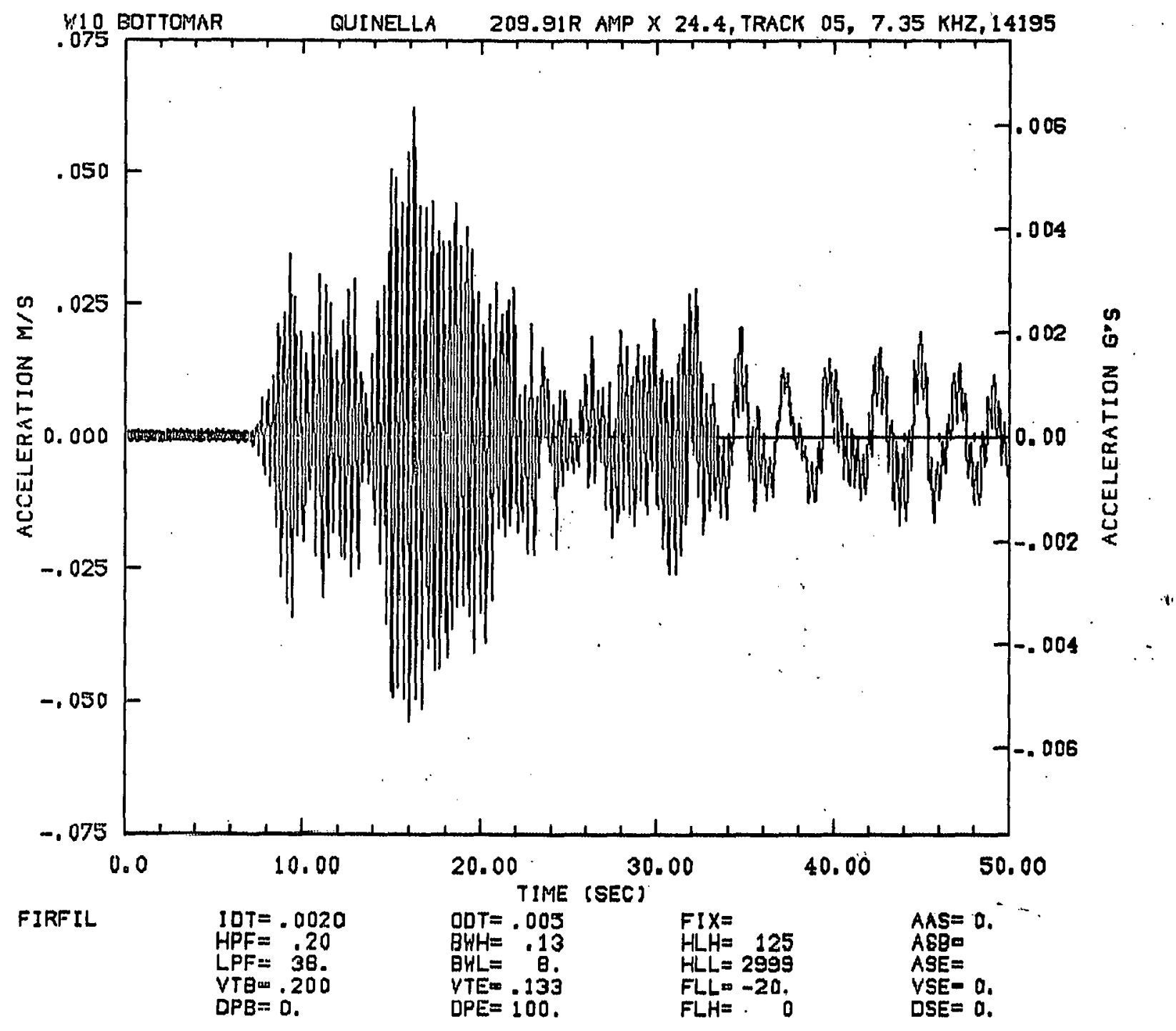

16.15 .23

$04 / 15 / 81$

Figure 3. Acceleration Record Containing Resonance 
- FARM

草

号 200

胥

昆

100

总

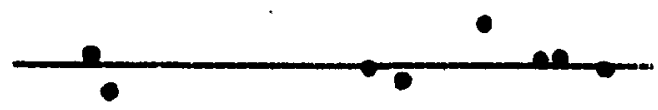

100 TIME IN DAYS

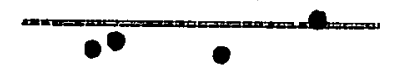

Figure 4. Chronological Record of Direction of Apparent First Motion 

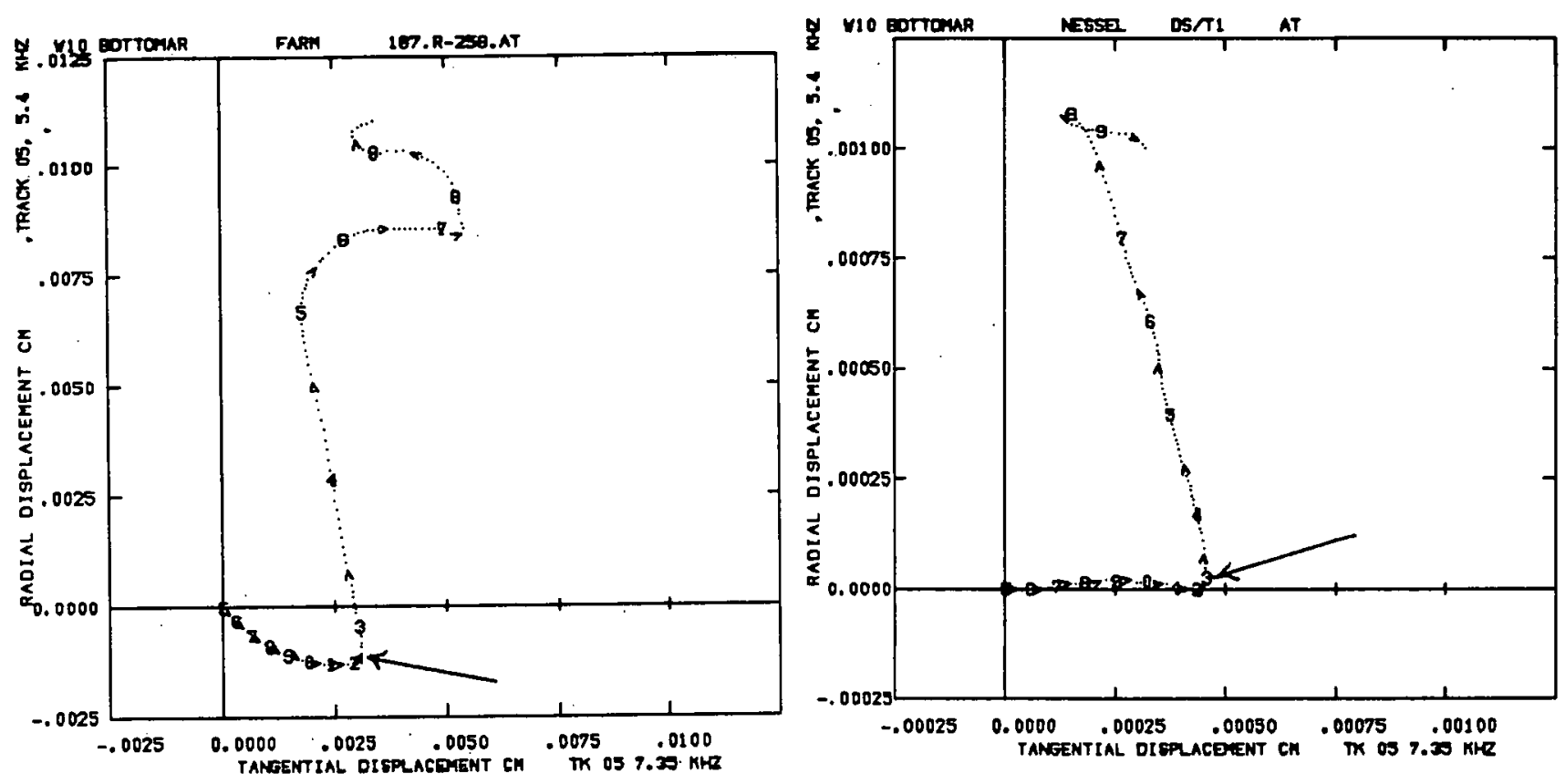

6.5
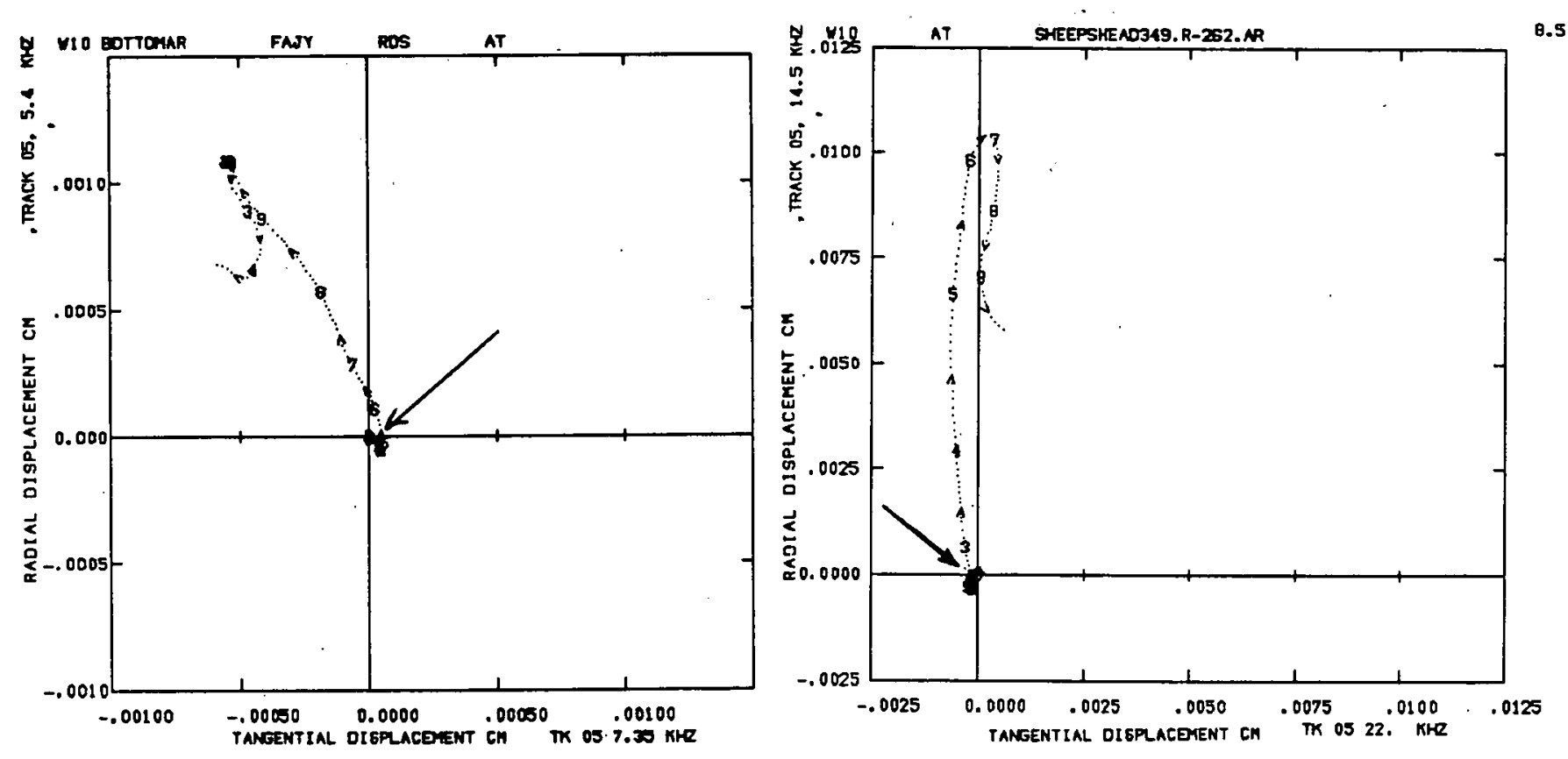

Figure 5. Typical Hodographs showing First Apparent Motion. Arrows indicate Time Selected as Signal Arrival Time. 


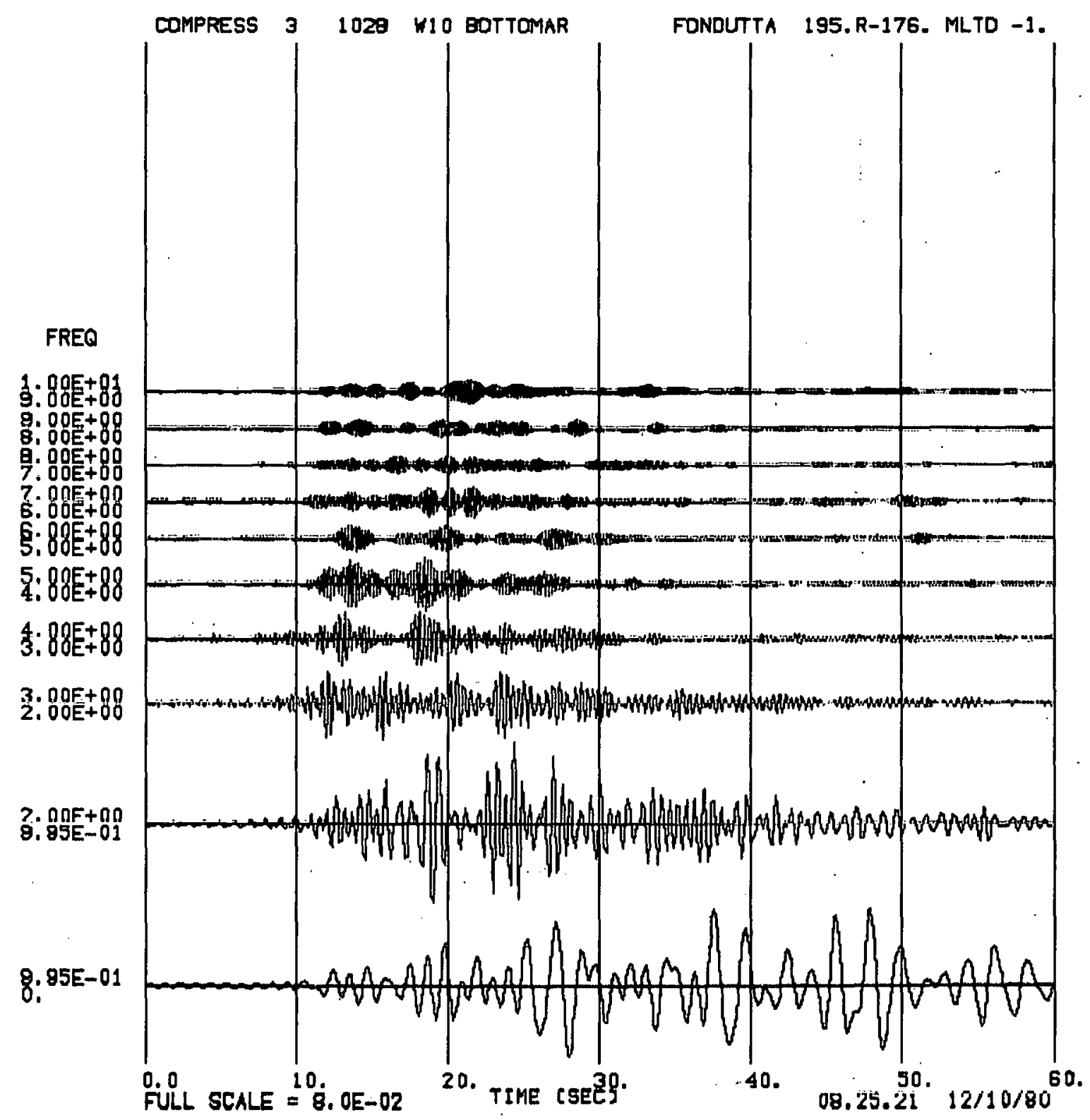

Figure 6. Typical Spectograph of Normal Data. 


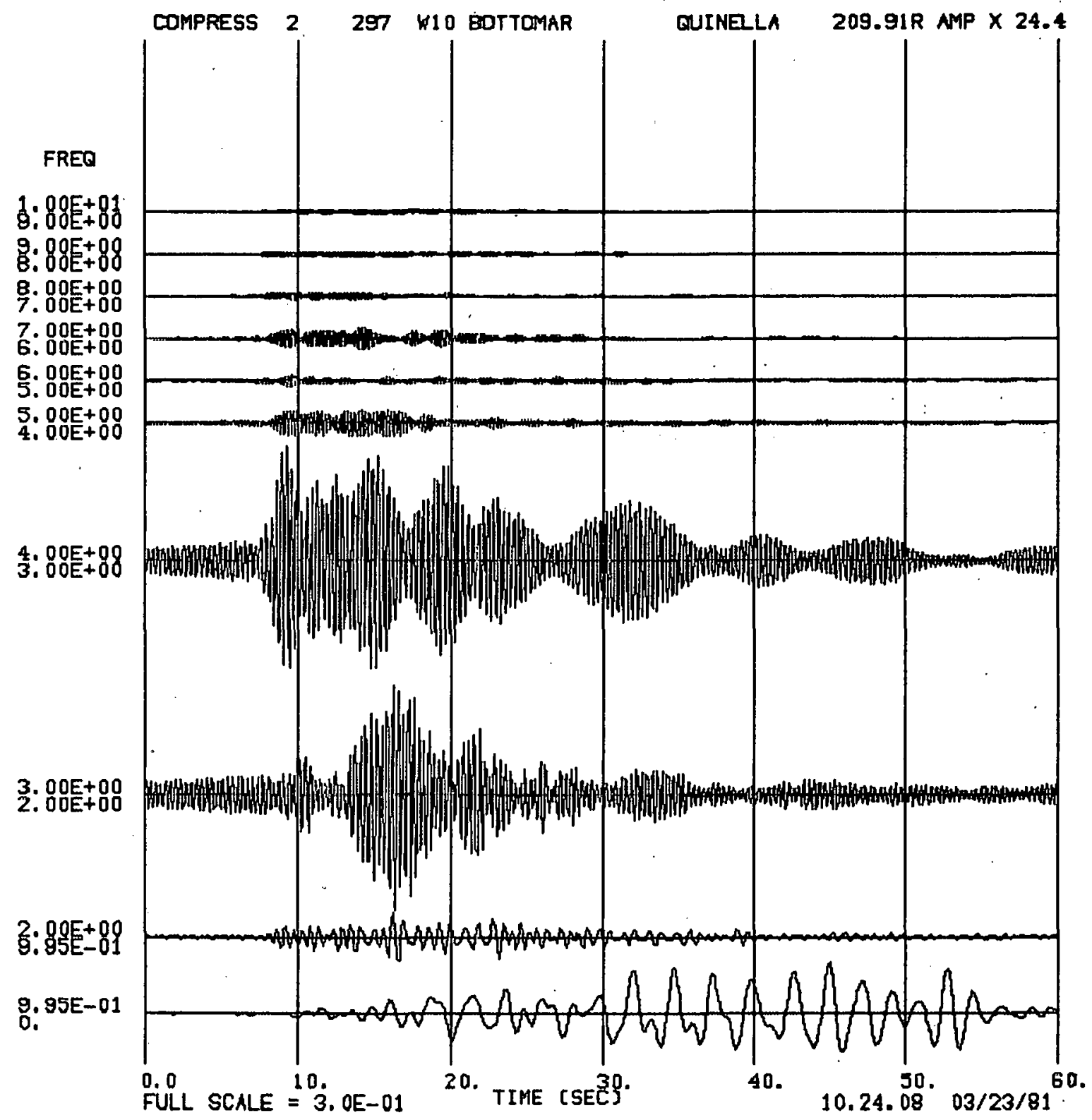

Figure 7. Spectograph for Radial Motion at W-10 Bottom on Quinella showing Unexplained Resonance. 


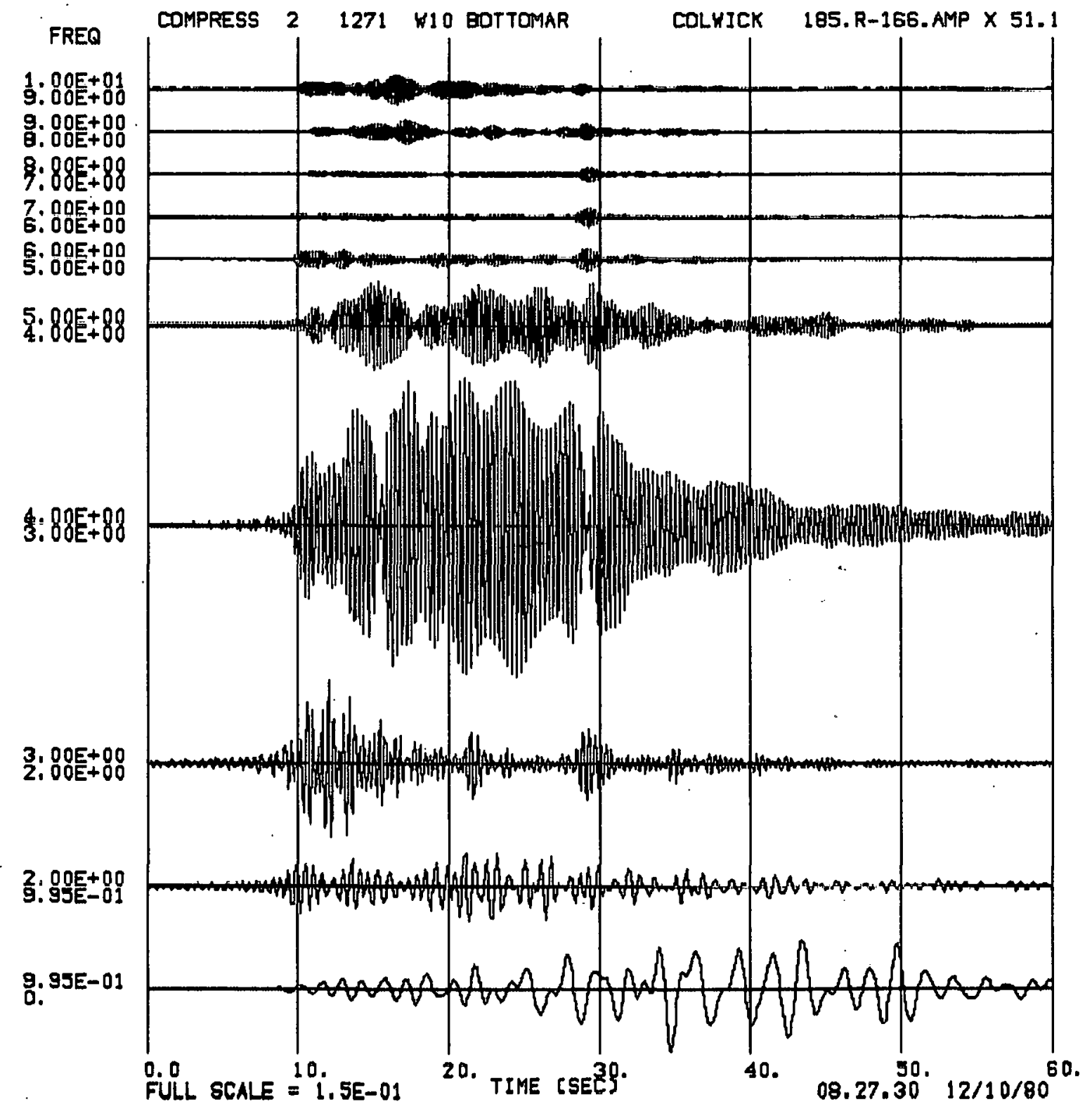

Figure 8. Spectograph for Radial Motion at W-10 Bottom on Colwick showing Unexplained Resonance is Still present. 


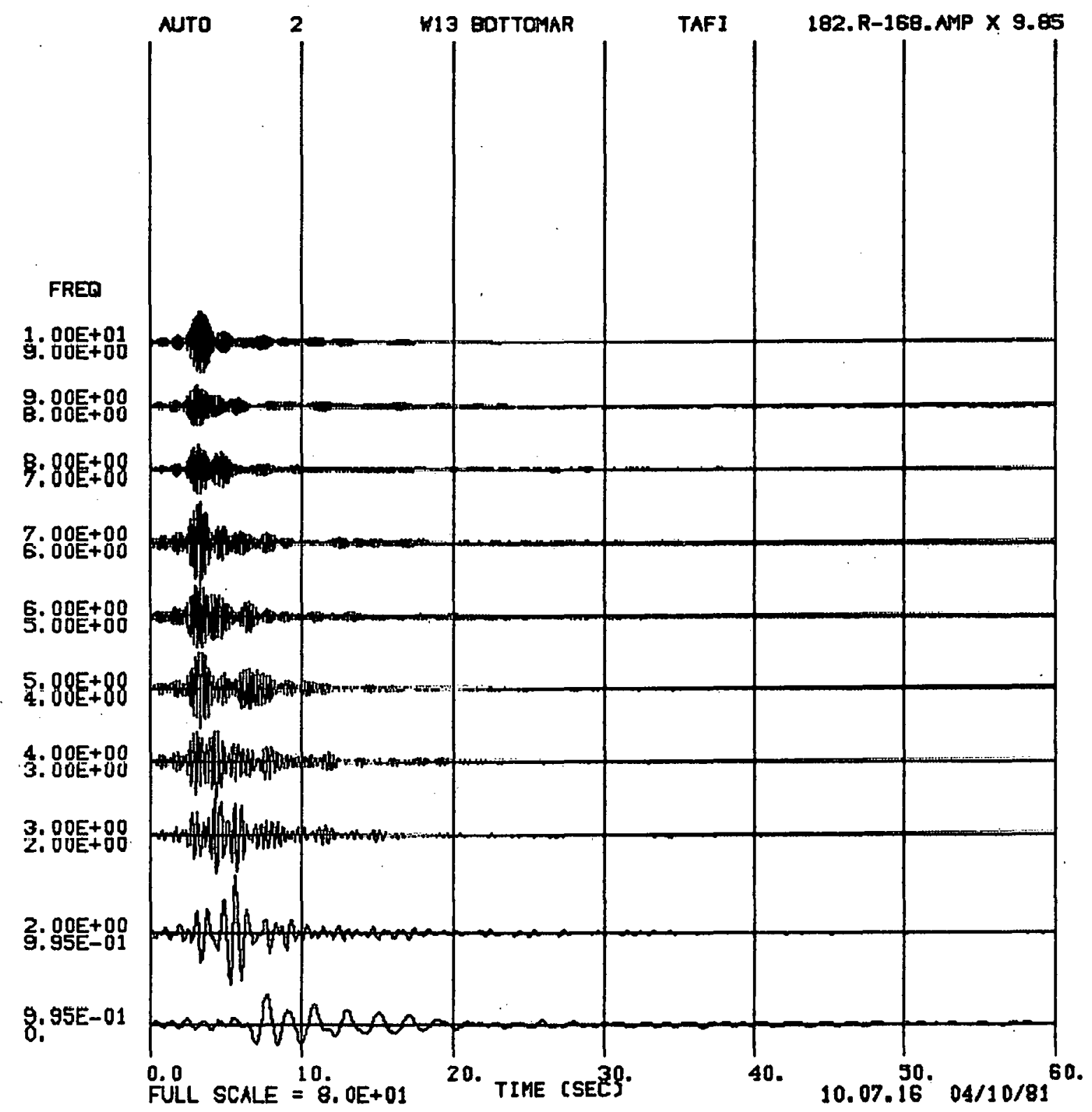
Figure 9. Spectograph of Radial Motion at W-13 Bottom on Tafi.




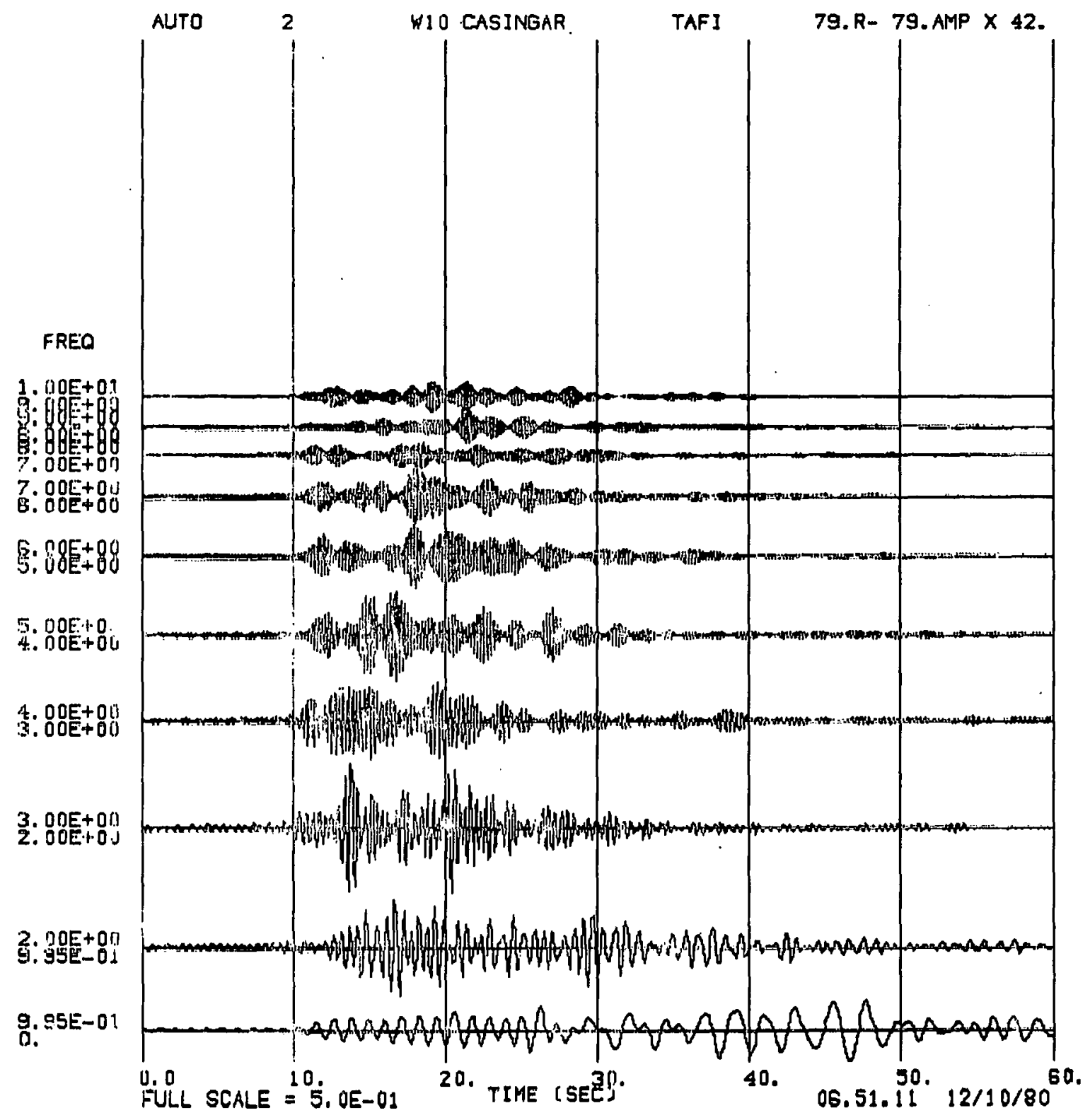

Figure 10. Spectograph of Radial Motion Recorded at Top of Well Casing on Tafi. 

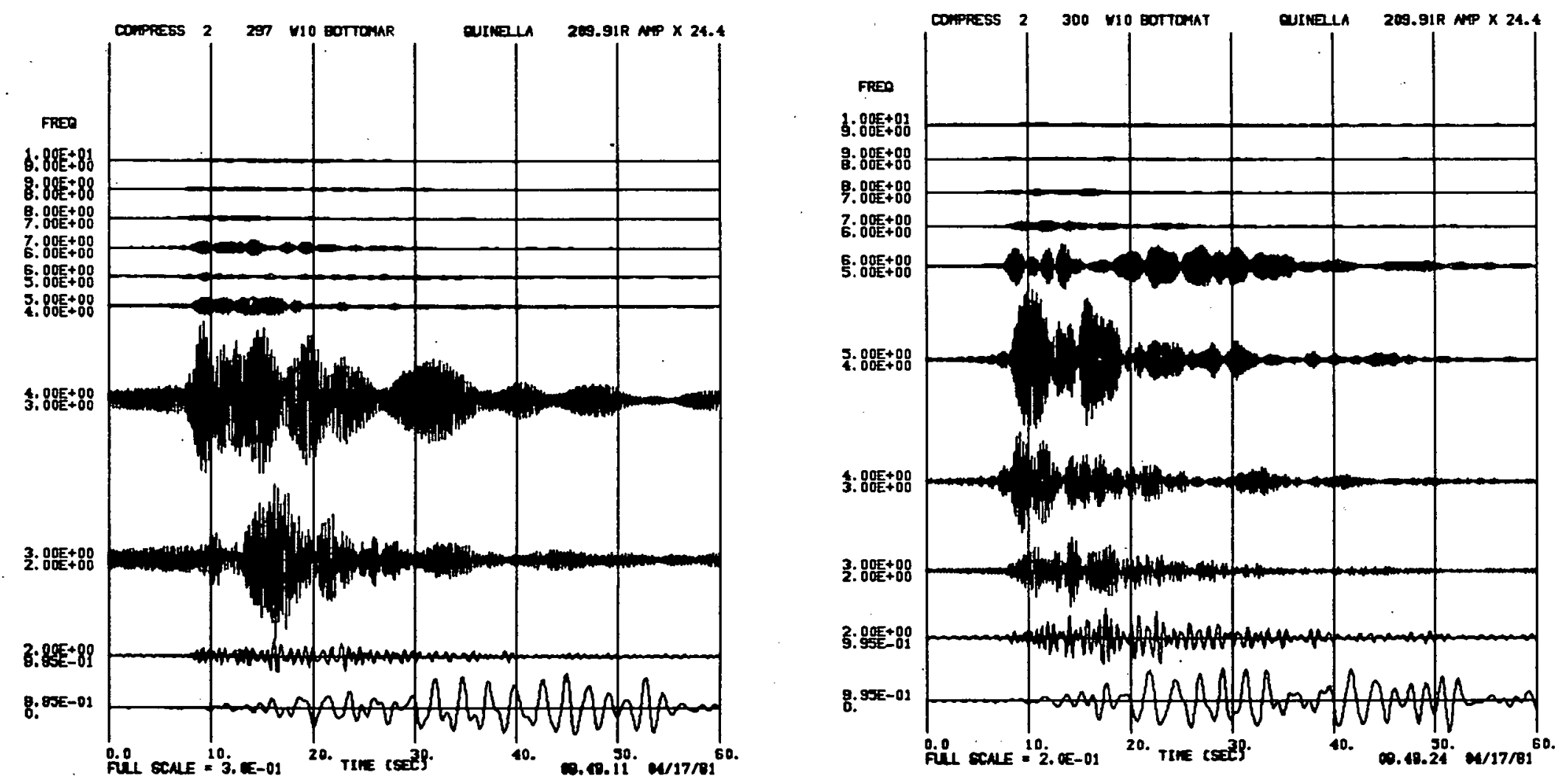

Figure 11. Spectographs of W-10 Bottom showing Dominance of Data by Resonant Frequencies of Approximately 3 and 5 Hertz. 


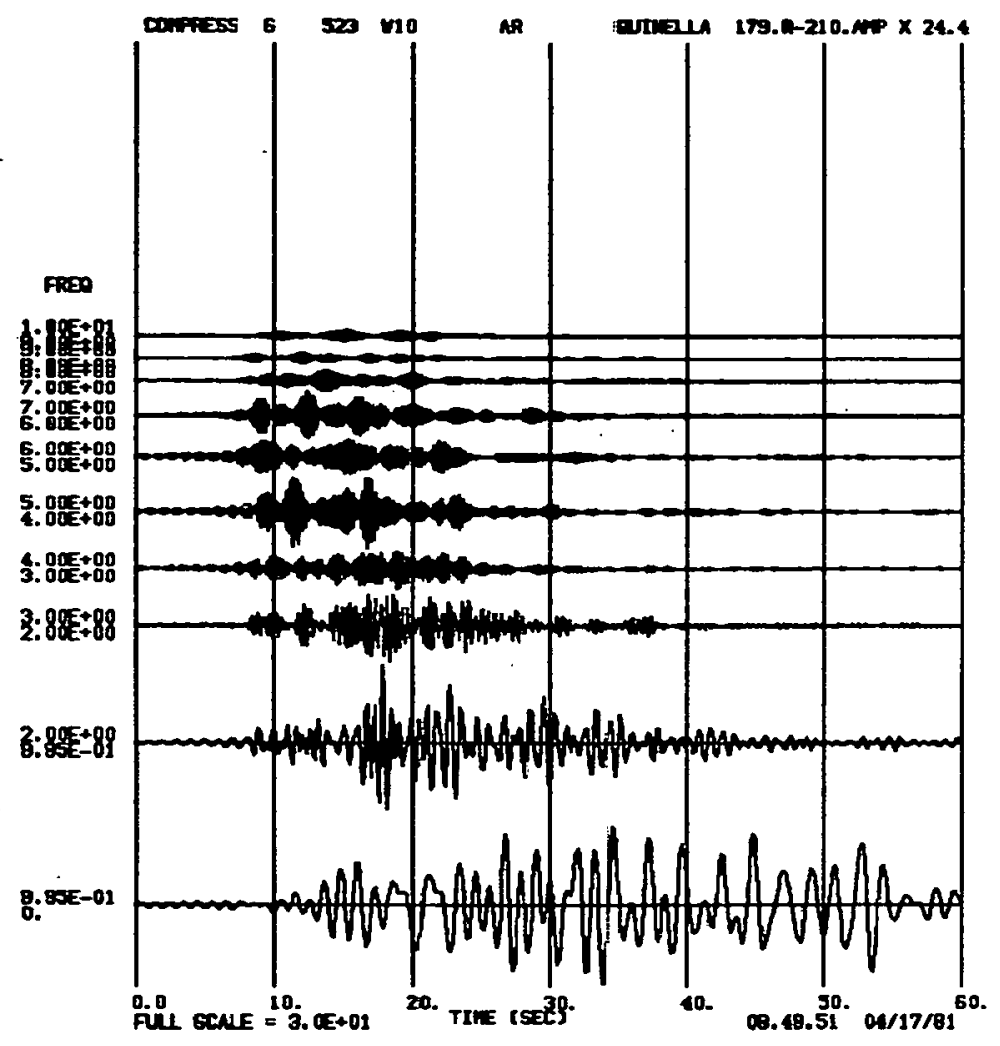

Figure 12A. Spectograph of Radial Motion at W-10 Prime as Processed.

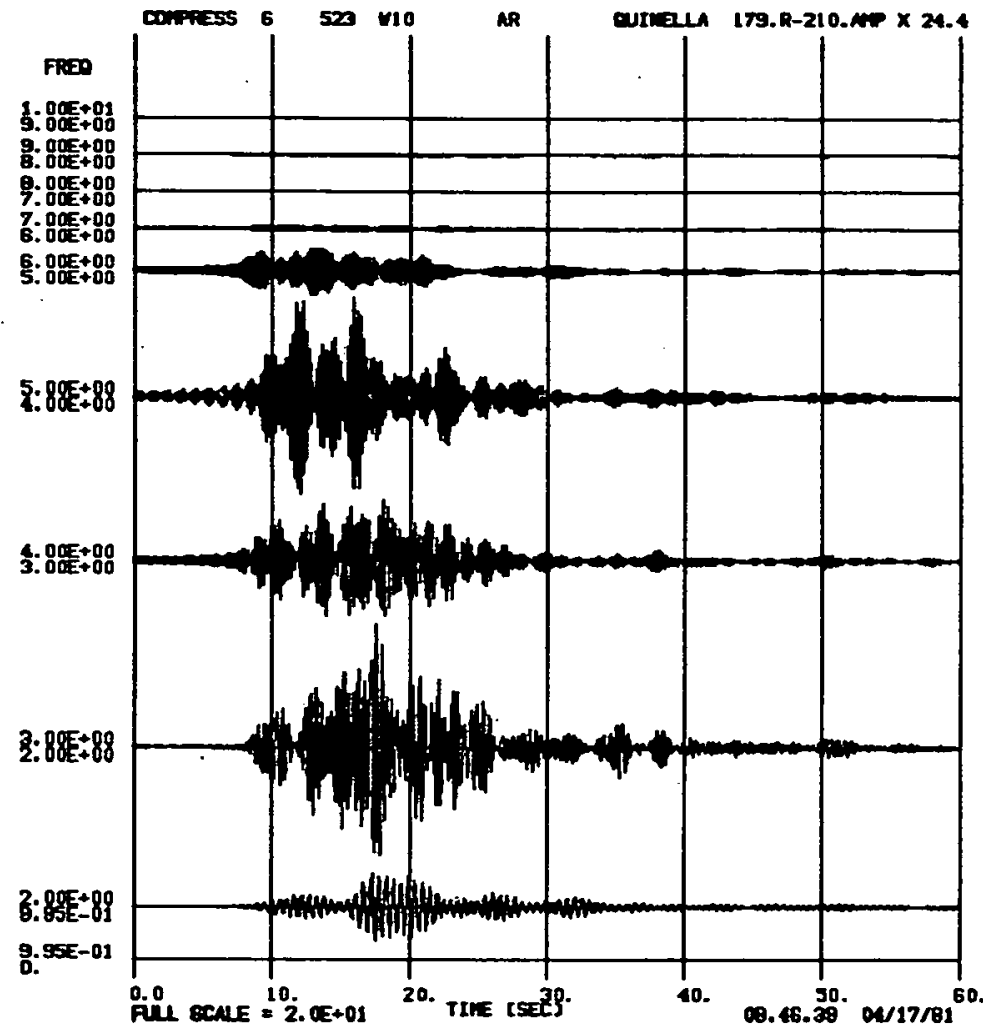

Figure 12B. Spectograph of Radial Motion at W-10 Prime after Filtering at 2 and 6 Hertz and Adjusting Amplitude. (Note Full Scale Change.) 


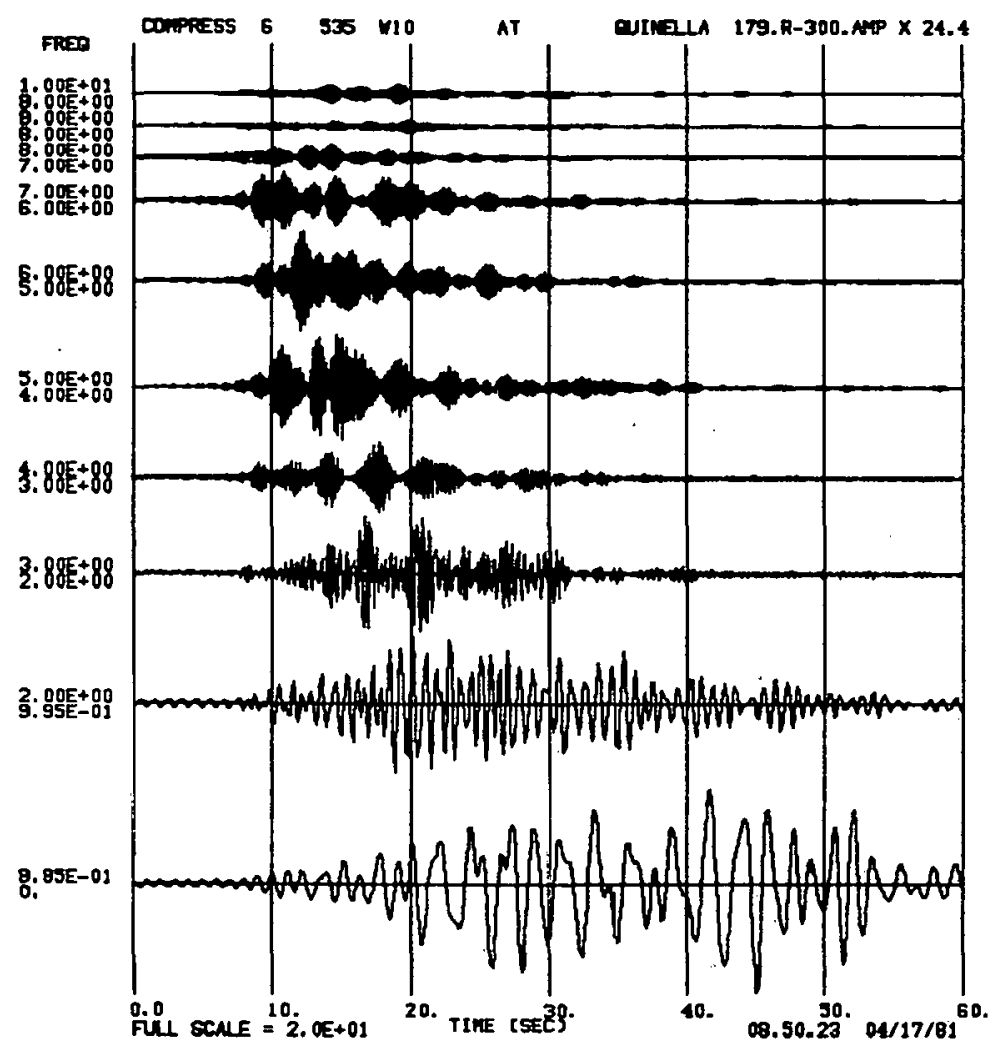

Figure 13A. Spectograph of Tangential Motion at $W-10$ Prime as Processed.

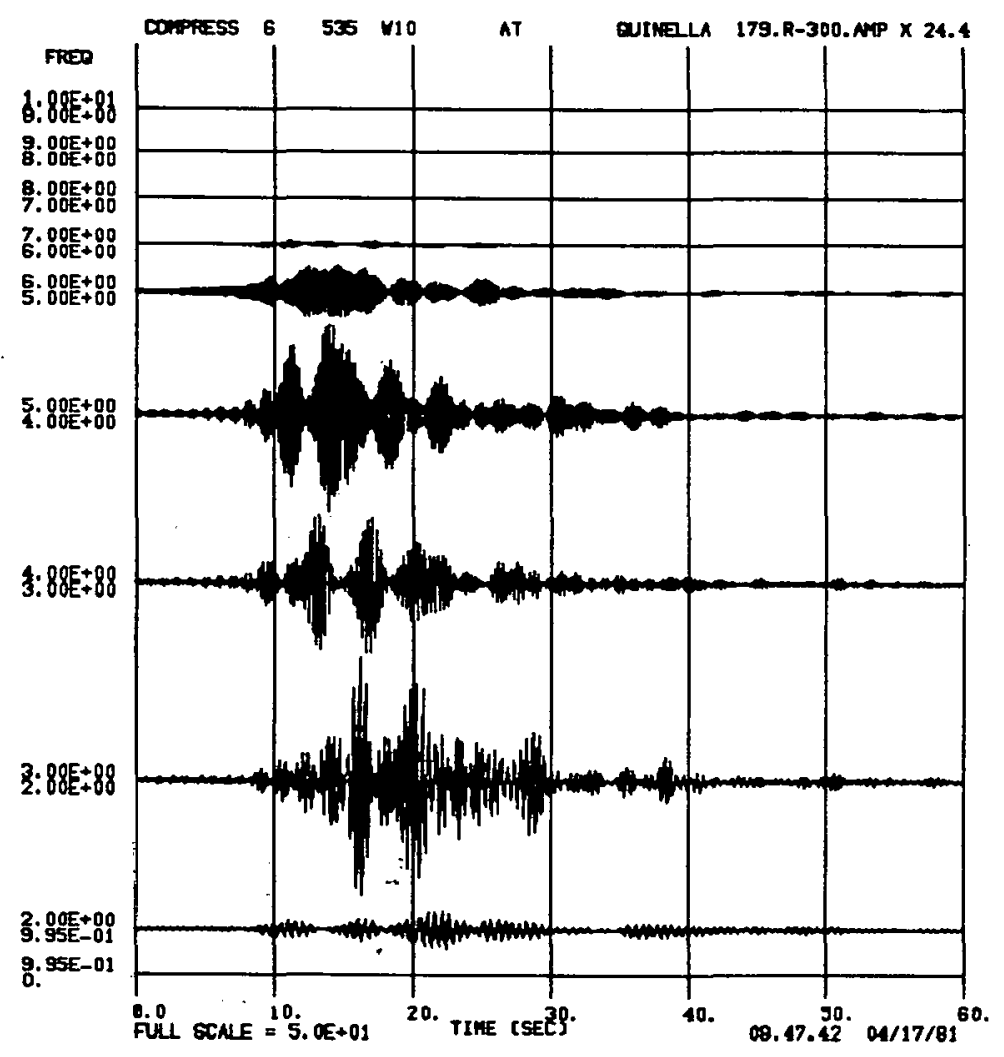

Figure 13B. Spectograph of Tangential Motion at W-10 Prime after Filtering at 2 and 6 Hertz and adjusting Amplitude. (Note Full Scale Change.) 


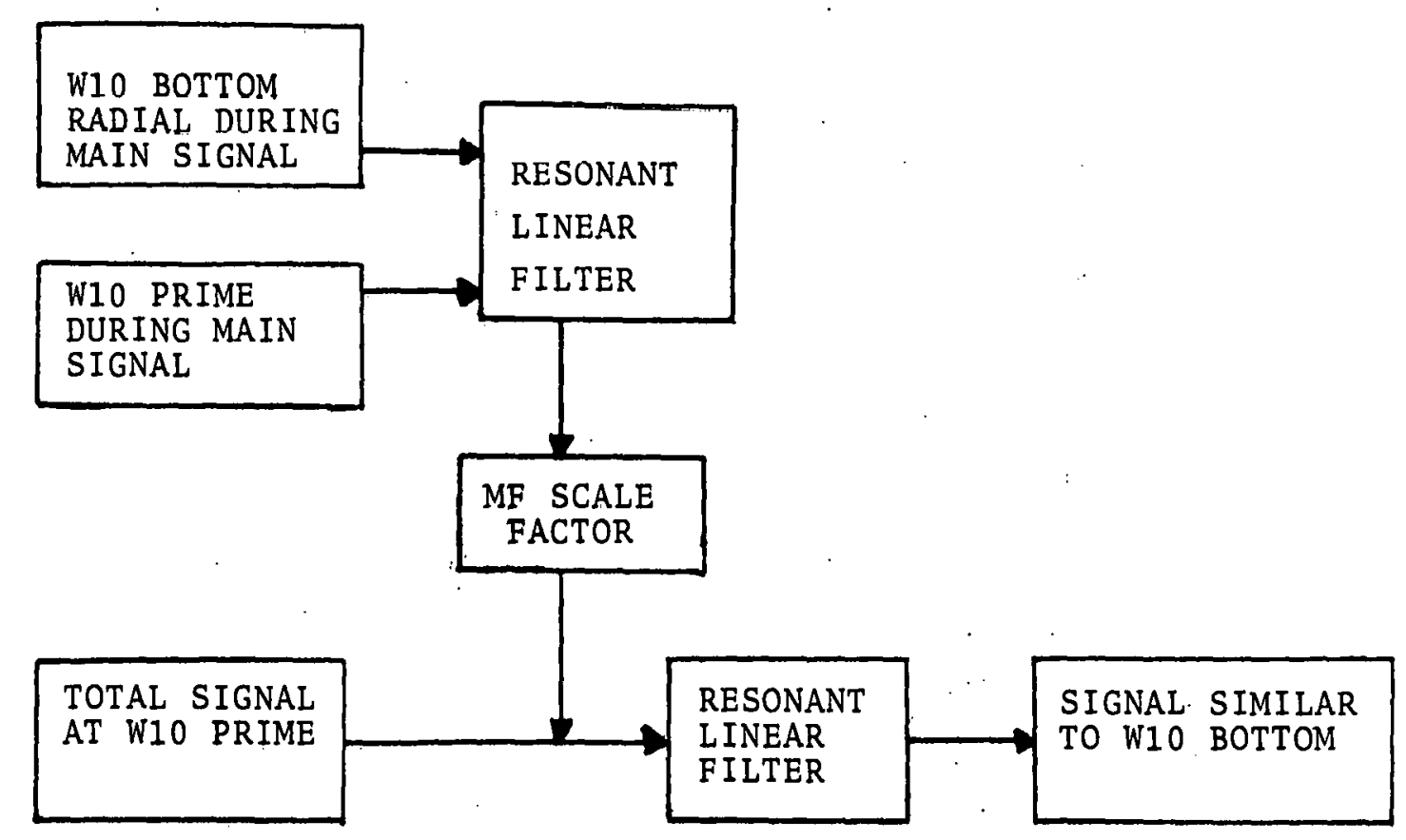

Figure 14 
Los Alamos National Laboratory (3) P.0. Box 1663

Los Alamos, NM 87545

Attn: D. D. Eilers, MS -420

J. Hopkins, MS-670

K. 01 sen, MS -676

U.S. Department of Energy (6)

Nevada Operations Office

P.0. Box 14100

Las Vegas, N.V 89114

Attn: W. F. Adams

L. M. Gard

J. K. Magruder

R. W. Newman

R. L. Reedom

R. H. Richards

T. E. Wade

U.S. Department of Energy (4)

Internal Security Affairs

20 Mass Avenue

Washington, DC 20545

Attn: G. F. Dickerson

J. L. Torres

U.S. Department of Energy

Library Branch

20 Mass Avenue

Washington, DC 20545

Holmes \& Narver, Inc.

P.0. Box 14340

Las Vegas, NV 89114

Attn: M. L. Rehkop, MS -580

REECO, InC.

P.0. Box 14400

Las Vegas, NV 89114

Attn: R. F. Parne11, MS-590

$E G \& G$, Inc.

P.0. Box 1912

Las Vegas, NV 89101

Attn: J.C. Tsitouras, MS $-570 / C-81$
U.S. Department of Energy

Military Applications

Washington, DC 20545

Attn: T. F. Cornwell

1100 C. D. Broyles

1110 J. D. Plimpton

1111 J. R. Banister

1111 J.W. Long (5)

1111 L. J. Vortman (5)

1112 C. R. Mehl

1120 T. L. Pace

1123

1123

1522

8214

3141

3151

B. C. Benjamin

R. V. Peet

G. L. West

M. A. Pound

L. J. Erickson (5)

W. L. Garner (3)

For DOE/TIC

$3154-3$

C. Dalin (25) 


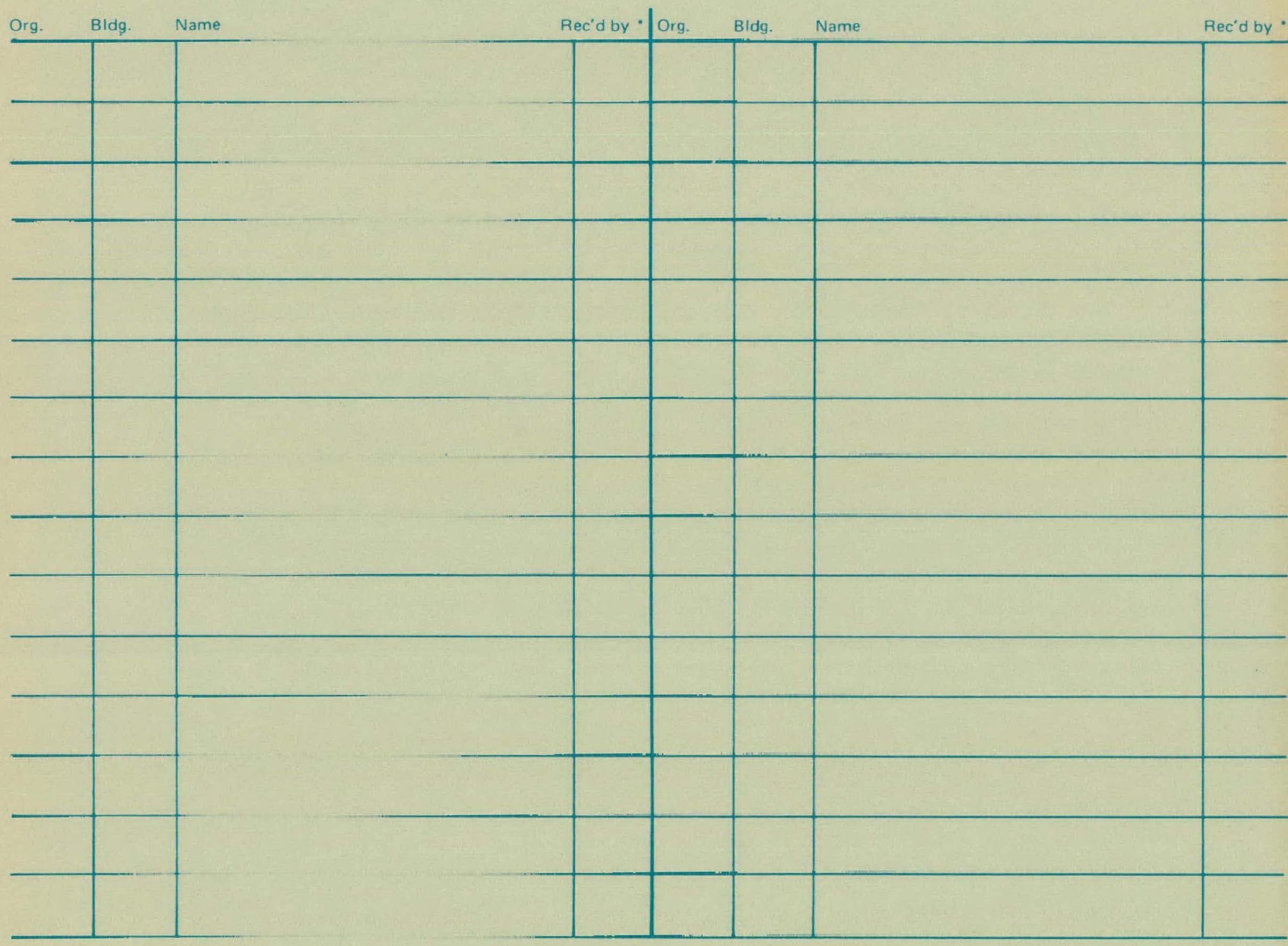

